\title{
Fauna of Protected Areas: 14 \\ DIVERSITY, ABUNDANCE, AND HABITAT ASSOCIATIONS OF BUTTERFLY SPECIES IN BONDLA WILDLIFE SANCTUARY OF GOA, INDIA
}

\author{
Manoj R. Borkar and Neelam Komarpant \\ Biodiversity Research Cell, Department of Zoology, Carmel College for Women, Nuvem, Goa \\ Email: neelak2@rediffmail.com
}

(web supplement $1653 l i \& I I i-i i)$

ABstract

Bondla Wildlife Sanctuary is a very popular wilderness destination for the tourists visiting Goa. One of smallest wildlife protected area in the state, its flora comprises of a mixture of evergreen and moist deciduous forests, besides some riparian patches. The tourist zone of the sanctuary has artificial landscape in form of animal enclosures, a formal garden and orchards. Against the backdrop of increasing interest in eco-tourism, it was envisaged to compile a species inventory of butterflies of this region, and find out the best seasons for butterfly sightings. The investigation on species diversity and abundance was carried out in three distinct habitat types, within the sanctuary viz. forests, orchards and formal gardens. Habitat associations of 91 butterfly species were determined by analyzing weekly sighting records from the three habitat types. The recorded species belonged to 66 genera, 14 subfamilies and five families. Nymphalidae dominated the list with 40 species, followed by Lycaenidae (19 species), Papilionidae (14 species), Pieridae (12 species), and Hesperiidae (6 species). Of the total butterfly species listed in this sanctuary, 71 species are habitat generalists and 20 species are habitat specialists, 13 figure in the scheduled categories of the Wildlife (Protection) Act, and eight are endemics. Based on the analysis of weekly data, flight periods and seasonality of species have been worked out. The findings have been based on one year of fieldwork. Species have been classified based on their relative estimates of abundance. Such studies on monitoring the species diversity and abundance of butterflies can give valuable information on their population dynamics.

KEYWORDS

Abundance, Bondla Wildlife Sanctuary, butterfly diversity, conservation status, flight periods, Goa, seasonal variations

Goa, being one of the states that contribute to the stretch of Western Ghats, has an amazing diversity of plant and animal life. The entire east zone of this state is a part of either of the four wilderness Protected Areas, viz., Madhei Sanctuary, Bondla Sanctuary, Netravali Sanctuary and Cotigao Sanctuary. Of these, the Bondla Wildlife Sanctuary is the smallest wildlife protected area in Goa, with an area of just $7.98 \mathrm{~km}^{2}$. Being declared as a game sanctuary, in January 1968 vide section 18 of Wild Animals and Wild Birds Protection Act 1965, Bondla boasts of a Mini Zoo, Deer Safari Park, Formal Gardens, Botanical Garden with a nursery and a few interesting icons which have been salvaged during excavations elsewhere in the state. Around $1.19 \mathrm{~km}^{2}$ of this sanctuary is set aside for the use of visitors. The vegetation of this sanctuary is predominantly mixed deciduous with intermittent patches of bamboo undergrowth. The flowing streams within the sanctuary create riparian patches.

Though great varieties of butterflies, moths and skippers are seen in this place supported by their food and host plants, there has been a complete dearth of authentic information on the lepidopteran fauna of Bondla Wildlife Sanctuary of Goa. The work presented here is based on the presumption that preparation of a checklist of butterflies, the most impressive element of insect diversity could bring about a lot of value addition to the potential of this sanctuary as an eco-tourism destination. Apart from check listing of butterfly species, an attempt has also been made to highlight their flight periods, seasonality and relative abundance in the different habitats of this sanctuary. The present study is undoubtedly the first comprehensive effort to investigate the lepidopteran diversity of the state of Goa in general and the area under investigation, the Bondla Wildlife Sanctuary in particular.

\section{Methodology}

The findings presented here are based on the field investigation carried out from July 2001 to June 2002. The fieldwork commenced only after obtaining permission from the office of the Director of Wildlife and Eco-tourism, Govt. of Goa vide letter No: 1-238-92-WLD-1270, under the UGC sponsored research program. The entire field protocol has been designed in compliance with the terms and conditions of the Wild Life (Protection) Act and its amendments.

To understand the diversity, abundance and habitat association of butterflies in this sanctuary, transects were laid in the three habitat types: Forests, Orchards and Gardens. Transects in each of the representative habitat were surveyed on foot every one day every week between $0900 \mathrm{hr}$ to $1700 \mathrm{hr}$ for a period of 46 weeks. Collection details and observations were recorded for subsequent computation and analysis. As a conservation policy, over collection was avoided and in fact, some rare specimen were collected only if doubts persisted in their specific identity.

The year was divided into three seasons viz. monsoons (June-

This paper was presented by the lead author at the $14^{\text {th }}$ All India Congress of Zoology held at Vivekananda College Agaastheeswaram, Kanyakumari on 21 23 December 2003. 
September), Post-monsoons (October-January) and Premonsoons (February- May), based on general observations on the climate. The relative abundance of butterfly species was determined adopting modification of the scheme proposed by Rajsekhar (1995). The butterflies were classified based on number of sightings in a single day of observation as follows: Abundant (>30\%), Very Common (10-30\%), Frequent (5-10\%), Occasional (1-5\%) and Rare $(<1 \%)$. The identification of butterfly species was based on standard keys provided by Wynter-Blyth (1957), Haribal (1992), and Kunte (2000). Collected specimens were subjected to detailed scrutiny through a comparative study with the reference material at the Bombay Natural History Society, Mumbai. The data has been compiled to determine seasonal variations in butterfly species diversity of this sanctuary.

\section{Results ANd Discussion}

In all 91 species belonging to 66 genera representing $12 \mathrm{sub}$ families and five families were recorded over a period of one year covering all seasons from July 2001 to June 2002. Of the total butterfly species listed in this sanctuary, 71 species were habitat generalists, whereas 20 species were habitat specialists, 13 figure in the scheduled categories of the Wildlife Protection Act, and eight are endemic (Table 1). Nymphalidae dominated the list with 40 species followed by Lycaenidae (19 species), Papilionidae (14), Pieridae (12) and Hesperiidae (6), respectively. Similar hierarchy pattern have also been reported from Parambikulam Wildlife Sanctuary by Sudheendrakumar et al. (2000).

It is apparent from the analysis of weekly records that the relative abundance of butterflies is species specific and under a distinct influence of seasons (Table $2^{\mathrm{w}}$ ). Further, the population dynamics of individual species vary in relation to habitat. Majority of papilionids and some members of Pieridae and Nymphalidae exhibit perennial occurrence; though varying in relative abundance. Seasonal variations in the relative abundance of species are more pronounced among lycaenids, hesperiids and some members of nymphalids. Among papilionids, Spot Swordtail and the jays show a smooth and predictable transition of relative abundance between rare and very common, reaching a peak in the summer months. The redbodied swallowtails have their flight period peak during the cooler months; and as far as the Common Mime is concerned, such a peak even gets extended into the early summer. The Blue Mormon is very common at least for a month during the transition between monsoons and post-monsoons. Red Helen has its flight period during the late monsoons and early winter. Species such as the Common Wanderer appear from mid monsoons and continue till the end of season.

As far as pierids are concerned, the yellows have very emphatic peaks of abundance lasting for as many as five months at a stretch as seen in case of Common Emigrant and the Small Grass Yellow during early winter. The Common Grass Yellow is abundant all through the monsoons, its relative abundance changing to very common throughout the winter until the

${ }^{w}$ See Table 2 on the web at www.zoosprint.org advent of summer.

The lycaenids are characterized by fairly discontinuous flight periods and seasonality. Some forms such as Angled Sunbeam, Monkey Puzzle, and Fluffy Tit though rare, occur in more than one season. Among the nymphalids, the browns and the rings have a greater relative abundance in the monsoons, steadily showing a decline throughout the cooler months until they become rare or absent in the dry summer months. The pansies are at their peak of abundance following rains. Among the pansies, the Soldier is predominant, maintaining a large population from the mid monsoons until the commencement of summer. On a scale of relative abundance, the Grey Pansy ranks next followed by the Peacock and Lemon Pansy, in order of declining abundance. The Blue and the Yellow pansies are rare, yet occur in the monsoons and post monsoons. Egg flies show peaks of abundance during the late winter months of December and January.

The Blue Oak Leaf is seasonal, confined to the monsoons. Among the sailors, the Common Sailor has flight period from mid August to early January with a peak in September whereas the Chestnut Streak variety is more restricted for its flight period during monsoons. The Colour Sergeant has a very sporadic occurrence. The Commander and the Grey Count show peaks of activity during the post-monsoons. The Common Baron occurs throughout the year, but shows a peak in the cooler months. Clipper shows peak activity during post-monsoons between October and December. Of the two Heliconiinae species, namely, Cruiser and Tamil Lacewing, the former is seen throughout the year with disjunctive occurrence whereas the latter is more active with the commencement of rains; with its population showing decline with the advent of post-monsoons. Tawny Coster, the only representative of Acraeinae appears in the monsoons, with a build up of its population in the post monsoon season. Among the danaiids, the Common Indian Crow is present round the year with distinct peaks in between late monsoon and early winter and on the eve of southwest monsoons.

Among the tigers, the Plain Tiger occupies the apex of the hierarchy of abundance followed by the Glassy, Striped and the Blue Tiger. The tigers normally reach the peak of their flight period in the post-monsoon months, whereas their population becomes scarce with the approach of summer. Malabar Tree Nymph, an endemic species of this region shows greater activity during the monsoons and post-monsoons, being absent in this range during the hotter months.

Thus, it is apparent that there are familial and specific variations in flight periods and seasonality. Such variations can be attributed to a synchrony with the phenology of food plants. In case of perennially occurring butterflies, availability of seasonal food plants round the year is implicated. In spite of the seasonal variations in the flight period of different species it is apparent that species diversity is distinctly high in certain seasons. For the area under investigation, the highest weekly averages for the number of species sighted are recorded for 


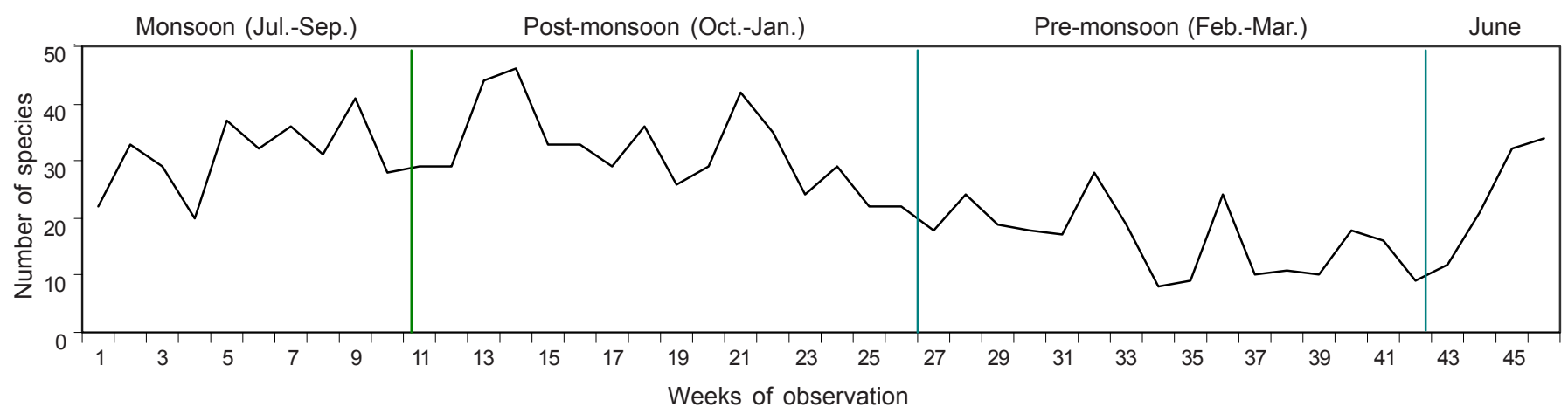

Figure 1. Seasonal variation in the butterfly species diversity of Bondla Wildlife Sanctuary, Goa

seasons extending from October to January (31.68\%). The average number of species sighted for monsoon season is next in rank $(28.92 \%)$, whereas the least average number is recorded for the summer season from February to May (16.06\%). Thus, species diversity of post monsoon months is emphatically higher suggesting that the months from October to January are ideal for butterfly sightings in the Bondla Wildlife Sanctuary (Fig. 1). The seasonal averages of species number for individual families are depicted in Fig 2.

Population dynamics of butterfly species as reflected through relative abundance reveal their habitat character and status. These insects select their habitat in relation to their food and host plants. Thus, it becomes imperative to understand the habitat associations for managerial interventions. The butterflies recorded from Bondla Wildlife Sanctuary reflect rich species diversity despite limitations of space. All the major families are represented in the butterfly fauna of this place, indicative of diverse habitats available. The least weekly count was nine species recorded during the first week of April and last week of May; whereas on the higher side, maximum of 46 species was recorded in the last week of October (Table 2).

Attributes such as abundance and density that are intrinsic to population of species are influenced by change of seasons. Thus, seasonal variations do occur in population sizes of many species of animal (Davidson \& Andrewartha 1948; Young 1982; Begon \& Mortimer 1986). Such dynamic changes in species population that closely follow seasonal variations are actually brought about by changes in photoperiod; which in turn cast an influence on floral phenology, reproductive behaviour and movements (Erlich, 1986). More often than not, it is a combination of influences rather than a single event that governs the population cycles.

Ideally the value of a tourist brochure of wilderness area would be greatly enhanced if the best season for sighting a particular faunal group were recommended. The application of this knowledge of population fluctuations is seminal to management and conservation of wildlife (May, 1980). As far as butterflies are concerned being phytophagous insects with fair degree of food and host plant specificity, their species diversity and richness is indicative of floral diversity of the habitat in which they occur. Thus it may be well known that a decline in the diversity of these fascinating insects is suggestive of habitat degradation. Conversely, habitat management is best option for management and conservation of butterfly species (Gilbert \& Singer, 1975; New, 1992). It implies therefore that habitat associations of butterflies have to be investigated. Regrettably much of the contemporary work on butterfly is restricted to simple inventory and checklists (Palot \& Soniya, 2001; Palot \& Abdurahman, 2003; Raju et al., 2003).

Interesting inferences can be drawn on habitat preferences recorded in this sanctuary (Table 1). Of the 91 species recorded here 20 are habitat specialists, among which 16 are forest dwellers and four are garden species. There is no exclusive orchard species. Of the remaining 71 species, 43 species occur in the entire sanctuary. Analysis of the records also reveals that orchards and garden together offer a better combination of habitat requirement, as 60 species are common to these two habitats. On a scale of commonality of species occurrence,

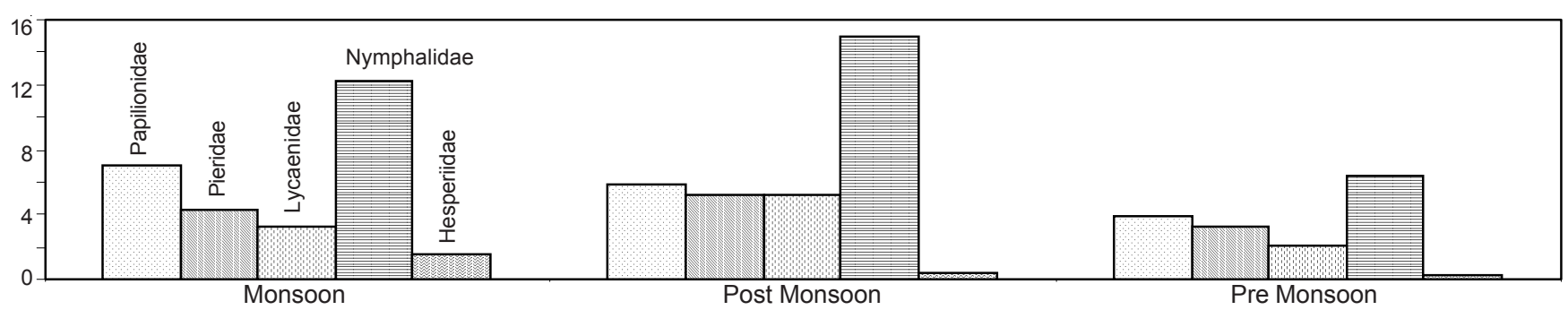

Figure 2. Seasonal averages of family contribution to the butterfly diversity of Bondla Wildlife Sanctuary, Goa 
Table 1: Habitat associations and conservation status of butterflies in the Bondla Wildlife Sanctuary, Goa

\begin{tabular}{|c|c|c|c|c|c|c|c|}
\hline \multicolumn{2}{|c|}{ SI.N Common names } & \multicolumn{2}{|l|}{ Scientific names } & \multicolumn{2}{|l|}{ Habitat } & \multirow[t]{2}{*}{ Status } & \multirow[t]{2}{*}{ Endemism } \\
\hline Papi & lionidae & & Forest & Orchard & Garden & & \\
\hline 1 & Spot Swordtail & Graphium nomius Esper & + & - & - & & \\
\hline 2 & Common Blue Bottle & Graphium sarpedon Linnaeus & + & + & + & & \\
\hline 3 & Tailed Jay & Graphium Agamemnon Linnaeus & + & + & + & & \\
\hline 4 & Common Jay & Graphium doson C \& R Felder & - & + & + & & \\
\hline 5 & Common Rose & Pachliopta aristolochiae Fabricius & - & + & + & & \\
\hline 6 & Crimson Rose & Pachiopta hector Linnaeus & + & + & - & Schedule I & \\
\hline 7 & Southern Birdwing & Troides minos Cramer & + & - & - & Schedule I & WG \\
\hline 8 & Common Mime Clytia) & Papilio clytia Linnaeus & + & - & + & & \\
\hline 9 & Common Mime (Dissimilis) & Papilio disimilis Linnaeus & + & - & + & & \\
\hline 10 & Lime Butterfly & Papilio demoleus Linnaeus & + & + & + & & \\
\hline 11 & Blue Mormon & Papilio polymnestor Cramer & + & + & + & & $\mathrm{PI} \& \mathrm{SL}$ \\
\hline 12 & Common Mormon & Papilio demoleus Linnaeus & + & + & + & & \\
\hline 13 & Red Helen & Princepes helenus helenus Hampson & + & - & - & & \\
\hline 14 & Malabar Banded Peacock & Papilio Buddha Westwood & + & - & - & Schedulell & WG \\
\hline \multicolumn{8}{|c|}{ Pieridae } \\
\hline \multicolumn{8}{|c|}{ Subfamily Pierinae } \\
\hline 15 & Psyche & Leptosia nina Fabricius & + & + & + & & \\
\hline 16 & Pioneer & Anapheis aurota aurota Fabricius & - & + & + & & \\
\hline 17 & Chocolate Albatross & Appias Lyncida elenora Boisduval & - & + & + & Schedule II* & \\
\hline 18 & Common Wanderer & Pareronia valeria hippia Cramer & + & + & + & & \\
\hline 19 & Dark Wanderer & Pareronia ceylonica & + & + & + & & \\
\hline 20 & Pale Wanderer & Pareronia avatar avatar Moore & - & + & + & & \\
\hline 21 & Common Gull & Cepora nerissa nerissa Fabricius & + & + & + & & \\
\hline 22 & Common Jezebel & Delias eucharis Drury & + & + & + & & SI \& SL \\
\hline \multicolumn{8}{|c|}{ Subfamily Coliadinae } \\
\hline 23 & Common Emigrant & Catopsilla Pomona Fabricius & + & + & + & & \\
\hline 24 & Mottled Emigrant & Catopsilla pyranthe Linnaeus & - & + & + & & \\
\hline 25 & Small Grass Yellow & Eurema brigitta rubella Linnaeus & + & + & + & & \\
\hline 26 & Common Grass Yellow & Eurema hecabe contubernalis Moore & + & + & + & & \\
\hline \multicolumn{8}{|c|}{ Lycaenidae } \\
\hline \multicolumn{8}{|c|}{ Subfamily Curetinae } \\
\hline 27 & Angled Sunbeam & Curetis dentata Moore & + & - & - & & \\
\hline \multicolumn{8}{|c|}{ Subfamily Theclinae } \\
\hline 28 & Large Oakblue & Arhopala amantes amantes Moore & + & - & - & & \\
\hline 29 & Yamfly & Loxura atymnus continentalis & - & - & + & & \\
\hline 30 & Common Acacia Blue & Surendra quercetorum quercetorum $\mathrm{M}$ & - & - & + & & \\
\hline 31 & Monkey Puzzle & Rathinda amor & + & - & - & & \\
\hline 32 & Common Imperial & Cneritra freja freja & & - & + & & \\
\hline 33 & Common Silverline & Spindasis vulcans fusca Moore & + & + & + & & IS \\
\hline 34 & Club Silverline & Spindasis syama peguanus Moore & + & - & - & & \\
\hline 35 & Fluffy Tit & Zeltus amasa & + & - & - & & WG \\
\hline 36 & Gram Blue & Euchrysops cnejus cnejus Fabricius & - & + & + & Schedule II & \\
\hline \multicolumn{8}{|c|}{ Subfamily Polyommatinae } \\
\hline 37 & Angled Pierrot & Caleta caleta decidia Cramer & + & + & + & & \\
\hline 38 & Common Cerulean & Jamides celeno celeno Cramer & + & + & + & & \\
\hline 39 & Pea Blue & Lamipes boeticus Linneaus & + & + & + & Schedule II & \\
\hline 40 & Dark Cerulean & Jamides bochus stoll Cramer & + & + & + & & \\
\hline 41 & Common Pierrot & Castalius rosimon rosimon & + & + & + & Schedule I & \\
\hline 42 & Dark Pierrot & Tarueus ananda & + & & + & Schedule IV & \\
\hline 43 & Red Pierrot & Talidcada nyseus Guerin-meneville & + & + & + & & \\
\hline 44 & Plains Cupid & Edales pandava Horsefield & - & + & + & & \\
\hline Subf & family Riodininae & & & & & & \\
\hline 45 & Plum Judy & Abisara echerius suffuse Moore & + & + & + & & \\
\hline Nym & phalidae & & & & & & \\
\hline Subf & family Satyrinae & & & & & & \\
\hline 46 & Common Evening Brown & Melanitis leda ismene Cramer & + & + & + & & \\
\hline 47 & Common Palmfly & Elymnias hypermenstra undularis & + & + & - & & \\
\hline 48 & Bamboo Tree Brown & Lethe ocellata lyncus De Niceville & - & + & + & & \\
\hline 49 & Nigger & Orsotrioena medus medus Fabricius & + & + & + & & \\
\hline 50 & Tamil Bush Brown & Mycalesus subdita & + & + & + & & \\
\hline 51 & Common Four Ring & Ypthima hubenri hubenri Fabricius & + & + & + & & \\
\hline 52 & Common Five Ring & Ypthima baldus baldus Fabricius & + & + & + & & \\
\hline 53 & Common Tree Brown & Lethe rhoria rhoria Linnaeus & + & - & - & & \\
\hline Subf & family Charaxinae & & & & & & \\
\hline 54 & Common Nawab & Polyura athamas athamas Drury & + & - & - & & \\
\hline
\end{tabular}




\begin{tabular}{|c|c|c|c|c|c|c|c|}
\hline \multicolumn{2}{|c|}{ SI.N Common names } & \multicolumn{2}{|l|}{ Scientific names } & \multicolumn{2}{|l|}{ Habitat } & \multirow[t]{2}{*}{ Status } & \multirow[t]{2}{*}{ Endemism } \\
\hline & & & Forest & Orchard & Garden & & \\
\hline \multicolumn{8}{|c|}{ Subfamily Nymphalinae } \\
\hline 55 & Angled Castor & Ariadne ariadne pallidior Frusthorfer & + & - & + & & \\
\hline & Common Castor & Ariadne merione assama Evans & + & - & + & & \\
\hline 57 & Rustic & Cupha erymanthis & + & + & + & & \\
\hline 58 & Common Leopard & Phalantha phalantha Drury & + & - & + & & \\
\hline 59 & Common Yeoman & Cirrochroa tyche mithila & + & - & - & & \\
\hline 60 & Yellow Pansy & Precis hierta magna Fabricius & - & + & + & & \\
\hline 61 & Blue Pansy & Precis orithya ocyale Linnaeus & - & + & + & & \\
\hline 62 & Lemon Pansy & Precis lemonias lemonias $(\mathrm{L})$ & + & + & + & & \\
\hline 63 & Peacock Pansy & Precis almana almana Linnaeus & + & + & + & & \\
\hline 64 & Grey Pansy & Precis atlites atlites Linnaeus & + & + & + & & \\
\hline 65 & Chocolate Pansy/Soldier & Precis iphita iphita Cramer & + & + & + & & \\
\hline 66 & Painted Lady & Cynthia carduii Linnaeus & + & + & - & & \\
\hline 67 & Danaid Eggfly & Hypolimnas missippus Linnaeus & + & + & + & Schedule I & \\
\hline 68 & Great Eggfly & Hypolimnas bolina Linnaeus & - & - & + & & \\
\hline 69 & Blue Oakleaf & Kallima horsefieldi Kollar & + & - & + & & \\
\hline 70 & Common Sailer & Neptis hylas varmona Moore & + & + & + & & \\
\hline 71 & Chestnut Streaked Sailor & Neptis jumbah jumbah Moore & + & + & + & Schedule I & \\
\hline 72 & Colour Seargent & Parathyma nafte inara & + & - & - & & \\
\hline 73 & Commander & Moduza procis procis Cramer & + & + & + & & \\
\hline 74 & Grey Count & Tanaecia lepidea lepidea (Butler) & + & - & + & Schedule II $^{*}$ & \\
\hline 75 & Common Baron & Euthalia aconthea suddhodana Frusthorfer & + & + & + & Schedule $\mathrm{II}^{*}$ & \\
\hline 76 & Clipper & Parthenos Sylvia Cramer & + & - & - & Schedule II & \\
\hline \multicolumn{8}{|c|}{ Subfamily Heliconiinae } \\
\hline 77 & Cruiser & Vindula erota erota & - & + & + & & \\
\hline 78 & Tamil Lace Wing & Cethosia nietneri nietneri & + & + & + & & SI \& SL \\
\hline \multicolumn{8}{|c|}{ Subfamily Acraeinae } \\
\hline 79 & Tawny Coaster & Acraea violae Fabricius & + & + & + & & \\
\hline \multicolumn{8}{|c|}{ Subfamily Danainae } \\
\hline 80 & Glassy Tiger & Parantica aglea melanoides (Moore) & + & + & + & & \\
\hline 81 & Blue Tiger & Tirumala limniace leopardus & - & + & + & & \\
\hline 82 & Striped / Common Tiger & Danaus(Salatha) genutia (Krammer) & + & + & + & & \\
\hline 83 & Plain Tiger & Danaus (Anosia) chrysippus (L) & + & + & + & & \\
\hline 84 & Common Indian Crow & Euploea core core (Cramer) & + & + & + & & \\
\hline 85 & Tree Nymph & Idea malabarica Moore & + & - & - & & WG \\
\hline \multicolumn{8}{|c|}{ Hesperiidae } \\
\hline 86 & Grass Demon & Edaspes folcus Cramer & + & + & + & & \\
\hline 87 & Indian Skipper & Spialia galbe Fabricius & - & + & + & & \\
\hline 88 & Dark Palm Dart & Telicota spp. & + & - & - & & \\
\hline 89 & Common Dart & Potanthus spp Fabricius & + & + & - & & \\
\hline 90 & Rice Swift & Borbo cinnara Wallace & + & + & + & & \\
\hline 91 & Tricolor Pied Flat & Psedocoladenia indrani Moore & - & + & + & & \\
\hline
\end{tabular}

+ - Species sighted, WG - Western Ghats, SL - Sri Lanka, IS - Indian Subcontinent, PI - Peninsular India, SI - Southern India

forest-garden combination ranks next with 52 species followed by forest-orchards complex with 48 . The progressive diminution in the species number supported by combination of two habitats may be ascribed to a corresponding decline in floral diversity (food plants), due to monoculture-like conditions prevailing in forests and orchards. The higher species richness of butterflies associated with gardens indicates availability of and access to food plants, besides being the most colourful domain in terms of floral diversity. This is further complemented by the lantana hedges here, which support a great diversity of butterflies. Though an exotic invasive species, Lantana camara is an important nectar source for several species of butterflies in degraded as well as urbanized habitat. Such a view has also been expressed by Raju and Reddy (1995) following their observation on the butterflies of Visakhapatnam.

The reasons for fewer habitat specialists can be understood if one takes into account the relatively smaller area of this sanctuary and proximity as well as confluence of discrete habitats.

\section{Conclusion}

Despite a very small area, this sanctuary is rich in butterfly species, representing all families. Fortunately, the tourist season in this state coincides very well with the best season for butterfly sightings in this sanctuary thereby enhancing its ecotourism potential. Further, a good deal of butterfly fauna of this wilderness area is endemic and has protected status as per the Indian Wildlife (Protection) Act, 1972. The situation reflects on the availability of diverse habitats as well as microclimatic zones. On the other hand the mounting pressures of Ecotourism on this sanctuary need to be carefully monitored. One of the most visited wilderness areas of Goa; recently this sanctuary was put on a fast track of Eco-tourism infrastructure development. Any change in landscape at the cost of wilderness here, shall prove detrimental to the butterfly diversity of this 
place; as the same would involve changes in land use pattern and loss of vegetation. Given remarkable species richness and endemism of butterfly species, Bondla Wildlife Sanctuary should not allow short term economic gains to prevail over its ecology.

\section{REFERENCES}

Begon, M. and M. Mortimer (1986). Population regulation. In: Population Ecology. UBS Publishers.

Davidson, J. and H.G. Andrewartha (1948). The influence of rainfall, evaporation and atmospheric temperature on fluctuations in the size of a natural population of Thrips imaginis (Thysanoptera). Journal of Animal Ecology 7: 200-222.

Erlich, P. (1986). The machinery of Nature. Paladin Publishers.

Gilbert, L.E. and M.C. Singer (1975). Butterfly ecology. Annual Review in Ecological Systematics 6: 365-397.

Haribal, M. (1992). Butterflies of the Sikkim Himalaya and its Natural History. Sikkim Nature Conservation Society Publication, Gangtok, $217 \mathrm{pp}$.

Kunte, K. (2000). Butterflies of Peninsular India. University Press (India) Limited, Hyderabad, 254pp.

May, R. (1980). Mathematical models in whaling and fisheries management, pp. 1-64. In: Oster, G.F. (Ed.). Some Mathematical Questions in Biology.

New, T.R. (1992). Conservation of butterflies in Australia. Journal of Research in Lepidoptera 29(4): 237-253.

Palot, J.M. and V.P. Soniya (2001). Additions to the butterflies of Keoladeo National Park, Bharatpur, Rajasthan, India. Zoos' Print Journal 16(9): 588.

Palot, J.M. and O.P. Abdurahman (2003). Butterfly collection at Entomology Museum, MES Mampad College, Kerala. Zoos' Print Journal 18(10): 1229-1231

Rajasekhar, B. (1995). A study on butterfly populations at Guindy National Park, Madras. Journal of the Bombay Natural History Society 92: $275-278$

Raju, A.J.S. and C.S. Reddi (1995). Flower colourshifts and pollination in Lantana camara L. Verbenaceae. Journal of Palynology 31: 275289.

Raju, A.J.S., S.P. Rao and V. Ezradanam (2003). Some ecological notes on the butterflies of Visakhapatnam, Andhra Pradesh. Zoos' Print Journal 18(6): 1126-1128.

Sudheendrakumar, V.V., C.F. Binoy, P.V. Suresh and G. Mathew (2000). Habitat associations of butterflies in the Parambikulam Wildlife Sanctuary, Kerala, India. Journal of the Bombay Natural History Society 97(2): 193-201.

Wynter-Blyth, M.A. (1957). Butterflies of the Indian Region. Bombay Natural History Society, Bombay, $523 \mathrm{p}$

Young, M.A. (1982). Effects of seasonality on insect's populations in the tropics. In: Population Biology of Tropical Insects. Plenum Press.

\section{ACKNOWLEDGements}

The lead author gratefully acknowledges the funds received from UGC Western Regional office, Pune under Minor Research Project 23-385/ 99(WRO) for conducting this study. Dr. R.M. Sharma Officer-in-charge of the High Altitude Station of Zoological Survey of India, Solan, Himachal Pradesh, has given valid suggestions in execution of this research project for which we owe our gratitude to him. The authors are also grateful to the Principal and Management of Carmel College of Arts, Science and Commerce for Women for the facilities provided at the Biodiversity Research Cell of Department of Zoology.

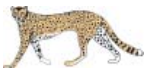

\section{MACROMORPHOLOGY OF THE TONGUE OF AN ASIAN ELEPHANT (ELEPHAS MAXIMUS)}

\section{Sarma, M. Talukdar, K.B. Dev Choudhury and K.K. Sharma}

Department of Anatomy and Histology, Assam Agricultural University, Guwahati, Assam 781022, India

(web supplement 1653i)

Macromorphology of the tongue was studied of a sub-adult Asian Elephant which died of an accident. The tongue was fixed in $10 \%$ neutral buffered formalin.

The tongue is light pink in colour and consists of three parts apex, body and root as in other domestic animals (Habel, 1975). The examined tongue was cone shaped, $24.50 \mathrm{~cm}$ in length, $7.88 \mathrm{~cm}$ wide and was $3.94 \mathrm{~cm}$ thick at the torus linguae.

The free rostral portion was the apex which constituted $1 / 3^{\text {rd }}$ of the total length. The remaining $2 / 3^{\text {rd }}$ was attached to the floor of the oral cavity. The apex presented the dorsal and ventral surfaces which met at the thin lateral borders. It was $1.87 \mathrm{~cm}$ in width and $1.66 \mathrm{~cm}$ thick at the tip.

The body was massive having four surfaces - two lateral on either sides, dorsal and ventral (attached to the floor). The dorsal surface was slightly rounded. The lateral surfaces were nearly flat. The ventral surface was related to the geniohyoideus and mylohyoideus muscles.

The torus linguae was present on the dorsum of the body and was not as prominent as in ruminants (Nickel et al., 1979). Fossa linguae were observed as a transverse shallow depression in between the apex and body. Similar observations were reported by Habel (1975) and Qayyum and Beg (1975) on ruminants. The mucosa on the torus was smooth. The root was caudal most part of the tongue being dorsoventrally flattened.

The dorsum of the tongue of elephant contained filiform, fungiform, lenticular and circum vallate papillae (Image $1^{\mathrm{w}}$ ). Conical papillae were not apparent. The numerous filiform papillae were observed throughout dorsum, fungiform were present on the rostral half of the dorsum and dorsolateral margins of the body. Lenticular papillae were observed on the lateral surfaces in the caudal $2 / 3^{\text {rd }}$ of the tongue. Circumvallate were present on the lateral aspect of the root of the tongue.

\section{REFERENCES}

Habel, R.E. (1975). pp. 86-87. In: Getty, R. (Editor). Sisson and Grossman's The Anatomy of the Domestic Animals. $5^{\text {th }}$ edition, W.B. Saunders Co., Philadelphia.

Nickel, R., A. Schummer and E. Seiferle (1979). Digestive System. pp. 65-66. In: The Viscera of the Domestic Animals. $2^{\text {nd }}$ edition. Verlag Paul Parey, Hamburg.

Qayyum, M.A. and M.A. Beg (1975). Acta Anatomica 93(4): 554 567.

${ }^{w}$ See Image 1 on the web at www.zoosprint.org

Manuscript 1065; Received 22 July 2003; Finally accepted 9 May 2004 (C) Zoo Outreach Organisation; www.zoosprint.org 